\title{
Multiproxy records of climate variability for Kamchatka for the past 400 years
}

\author{
O. Solomina ${ }^{1}$, G. Wiles ${ }^{2}$, T. Shiraiwa ${ }^{3}$, and R. D'Arrigo ${ }^{4}$ \\ ${ }^{1}$ Institute of Geography RAS, 119017 Staromonetny-29, IGRAS, Moscow, Russia \\ ${ }^{2}$ The College of Wooster, Wooster, Ohio, USA \\ ${ }^{3}$ Research Institute for Humanity and Nature, Kyoto, Japan \\ ${ }^{4}$ Tree Ring Laboratory, Lamont Doherty Earth Observatory, Palisades, New York, USA \\ Received: 4 August 2006 - Published in Clim. Past Discuss.: 1 November 2006 \\ Revised: 7 February 2007 - Accepted: 9 February 2007 - Published: 22 February 2007
}

\begin{abstract}
Tree ring, ice core and glacial geologic histories for the past several centuries offer an opportunity to characterize climate variability and to identify the key climate parameters forcing glacier expansion in Kamchatka over the past 400 years. A newly developed larch ring-width chronology (AD 1632-2004) is presented that is sensitive to past summer temperature variability. Individual low growth years in the larch record are associated with several known and proposed volcanic events from the Northern Hemisphere. The comparison of ring width minima and those of Melt Feature Index of Ushkovsky ice core helps confirm a 1-3 year dating accuracy for this ice core series over the late 18th to 20th centuries. Decadal variations of low summer temperatures (tree-ring record) and high annual precipitation (ice core record) are broadly consistent with intervals of positive mass balances measured and estimated at several glaciers in 20th century, and with moraine building. According to the tree-ring data the 1860s-1880s were the longest coldest interval in the last 350 years. The latest part of this period (1880s) coincided with the positive anomaly in accumulation. This coincidence led to a positive mass balance, which is most likely responsible for glacier advances and moraine deposition of the end of 19th-early 20th centuries. As well as in some other high latitude regions (Spitsbergen, Polar Urals, Franz Jozef Land etc.) in Kamchatka these advances marked the last millennium glacial maximum. In full agreement with subsequent summer warming trend, inferred both from instrumental and tree ring data, glacier advances since $1880 \mathrm{~s}$ have been less extensive. The late 18th century glacier expansion coincides with the inferred summer temperature decrease recorded by the ring width chronology. However, both the advance and the summer temperature decrease were less prominent that in the end of 19th century. Comparisons of the glacier history in Kamchatka with records from Alaska
\end{abstract}

Correspondence to: O. Solomina

(olgasolomina@yandex.ru) and the Canadian Rockies suggests broadly consistent intervals of glacier expansion and inferred summer cooling during solar irradiance minima.

\section{Introduction and study area}

Modern, near-global retreat of glaciers in response to rising temperatures is a clear demonstration of the relevance of glacier variations as a climate proxy (Oerlemans, 2001; Hoelzle et al., 2003). However the accuracy of moraine dating, the uncertain time lag between the climatic signal and glacier fluctuations, as well as the unknown relative contribution of various climate forcings have limited the use of glacial histories in modern quantitative reconstructions. The interpretation of the climatic significance of advance or retreat has also been a limitation on the use of these glacial geologic data as the signal can be interpreted as a mixture of precipitation and temperature. In Kamchatka this question is particularly relevant as this is a coastal region, similar in climate to coastal Norway and New Zealand where glacier behavior may, in part, be strongly regulated by precipitation as well as temperature (Muraviev et al., 1999; Chinn, 1999; Nesje and Dahl, 2003).

The Kamchatka Peninsula $\left(56^{\circ} \mathrm{N} 160^{\circ} \mathrm{E}\right)$ is $1600 \mathrm{~km}$ long, and up to $500 \mathrm{~km}$ wide at its widest (Fig. 1) and supports 29 active and about 300 extinct volcanoes. Most of the glaciers of Kamchatka (446 glaciers covering about $900 \mathrm{~km}^{2}$ ) are located in the Sredinny and Eastern Ranges, along the coast of the Peninsula (Fig. 1). The orientation of the mountain ranges protects the inner regions of the Peninsula from the influence of the North Pacific so that the climate in the interior is more continental. The climate along the coastal margins is cool and maritime. Annual precipitation is $600-1100 \mathrm{~mm}$ in the high mountains ranges and up to $2500 \mathrm{~mm}$ along the coast. Mean annual temperature is about $0^{\circ} \mathrm{C}$ in the south at Petropavlovsk-Kamchatsky city. Winters are cool, snowy

Published by Copernicus GmbH on behalf of the European Geosciences Union. 


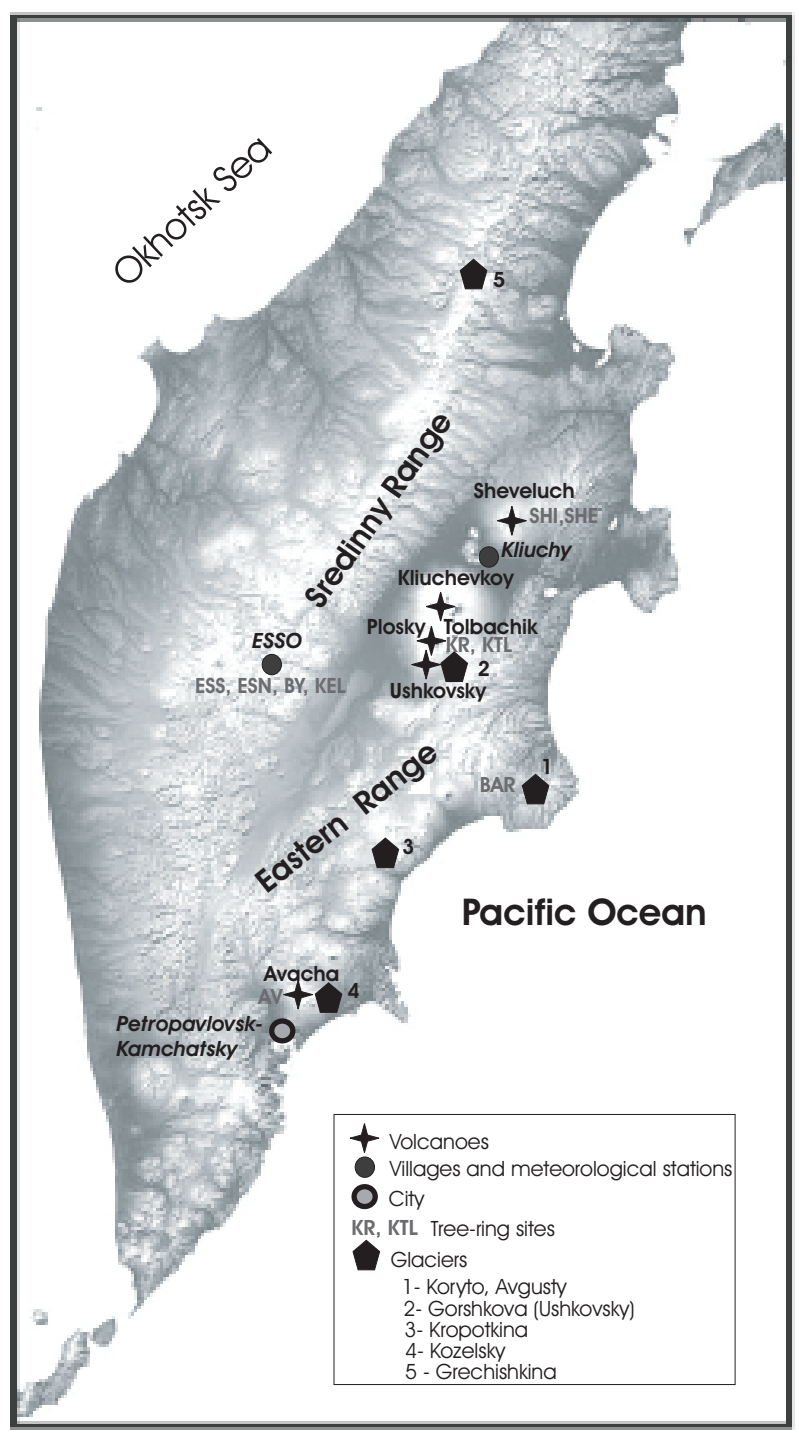

Fig. 1. Study area showing the location of tree-ring, glacier, ice core sites and meteorological stations used in this study.

and windy, and summers are wet and cloudy. Glaciers occupy a wide altitudinal range from 300 to $4500 \mathrm{~m}$ a.s.l. and equilibrium line altitudes range from $700 \mathrm{~m}$ in the Kronotsky Peninsula to $2800 \mathrm{~m}$ on Kliuchevskoy volcano (Fig. 1). Four vegetation belts are distinguished on the slopes of the mountains facing the Central Kamchatka depression. The dendroclimatically important species, spruce and larch (Larix cajandery Mayr.) forests grow generally up to 300-350 m elevation and in places larch trees rise up to $1000 \mathrm{~m}$. Stone birch (Betula ermanii Cham.) reach up to $600-800 \mathrm{~m}$ and creeping pine, alder, and willow reach altitudes up to $1000 \mathrm{~m}$. Alpine meadows and mountain tundra dominate the elevation near the glaciers.

Historical descriptions of glaciers in Kamchatka go back to the early 20th century with mass balance measurements at several glaciers begun during the International Geophysical Year in 1957 (Vinogradov, 1975; Vinogradov and Muraviev, 1992). In order to extend these observations into the past, moraines have been dated using tree-rings, lichenometry, tephrochronology and radiocarbon (Solomina, et al., 1995; Solomina, 1999; Golub, 2002). Solomina and Calkin (2003) summarized these results and determined the main periods of glacier advance for the last 400 years.

This study adds to the growing development and analysis of proxy records from the western North Pacific Rim including the Kurile Islands (Jacoby et al., 2004; Solomina et al., 2005), and Hokkaido, Japan (Davi et al., 2002). Much of the motivation in exploring the variability across the Pacific basin was spurred by the 1976 transition in Pacific climate and the subsequent interest in Pacific Decadal Variability (Mantua et al., 1997).

In this paper we compare the glacial histories in Kamchatka with two climatic proxies: a ring-width based warmseason temperature record, and an ice-core based annual precipitation record (Shiraiwa et al., 1997, 1999, 2001). This comparison helps to identify the climatic signals related to glacier advances in Kamchatka as solid precipitation and summer temperature are the two primary drivers of glacier mass balance (Patterson, 1994). Glaciers act as a low-pass filter responding to decadal and century-scale climate changes by length changes. Due to the low frequency nature of the glacier record, we use smoothed values of the annually-dated tree-ring and ice core proxies to emphasize the decadal fluctuations for comparison with the glacier record. We also use the inferred temperature histories based on ring-width data and the Melt Feature Index (MFI) from the Ushkovky ice core to provide an assessment of the dating accuracy of the ice core records.

\section{Climate and proxy records}

\subsection{Climate}

Meteorological records, tree-ring chronologies, ice cores and glacier moraines used in this paper (Fig. 1) were primarily chosen with the goal of understanding regional climate change and glacier response to this change.

Regular meteorological observations in Kamchatka began in the 1880s in Petropavlovsk, which is located at the Pacific coast in southern Kamchatka. The climate of the inner Kamchatka is substantially different from the southern maritime regions therefore we used the shorter observations for Kliuchy and Esso meteorological stations which are located in the vicinity of most of our proxy records (Fig. 1). The climate data were obtained from http://climate.mecom. ru/climate/bulletins/bul03v02.pdf.

Recent (1920s-2000) trends in temperature and precipitation in inner Kamchatka are best represented from Kliuchy (Fig. 2a, b). Temperature records from Kliuchy station 


\section{A TEMPERATURE}
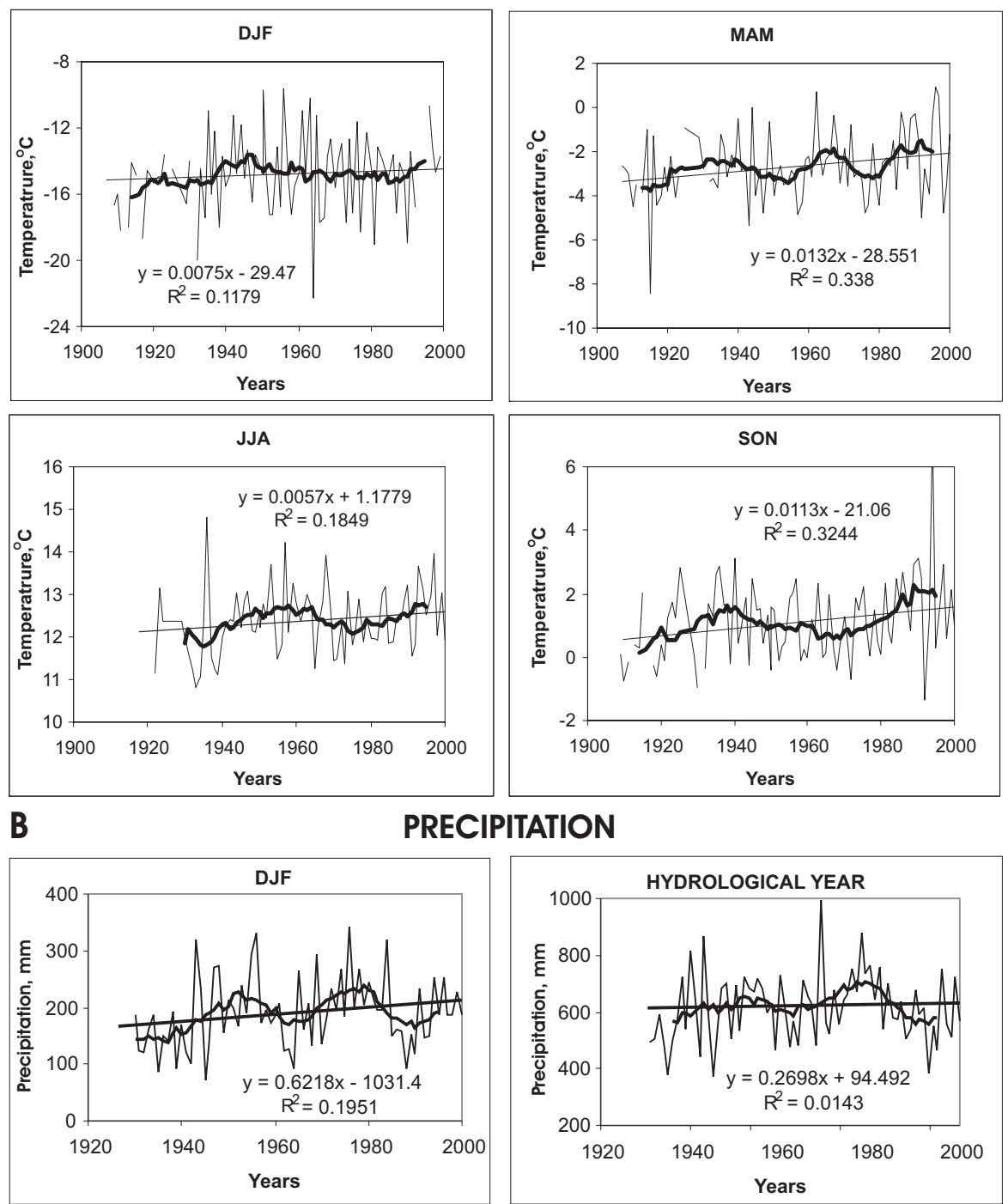

Fig. 2. Temperature (A) and precipitation (B) record from Kliuchy meteorological station in Kamchatka.

(Fig. 2a) reflect the influence of the Siberian anticyclone and cold current along the coast. There are significant positive trends in the fall, spring and summer with warming becoming more pronounced in 1970s. The instrumental record at Kliuchy also shows an increase in winter (DJF) precipitation in central Kamchatka since the 1930s (Fig. 2b). A coherence of temperature variations with PDO is evident in the smoothed records (e.g. 11-years running mean, Fig. 3b), however one can also see that the relationship is not stable through time, and there is a substantial difference between southern maritime and northern "continental" records.

\subsection{Tree ring records}

Few tree-ring records are available for Kamchatka and most chronologies have been developed from the interior of the Peninsula where the extensive larch forests thrive. In one of the first dendroclimatic studies Gostev et al. (1996) used a larch ring width chronology from 12 living trees at the Bystraya site (BY; Table 1; Fig. 1), to estimate early summer temperature. This preliminary reconstruction explained 38\% of the variance of May-June temperature. More chronologies have subsequently been developed (Table 1) including larch ring-width series from three locations near the upper tree limit in the vicinity of the Village of Esso (ESS, ESN, KEL), two sites from the upper tree line at Tolbachik (KR, KTL), a chronology from the Shiveluch active volcanoes 
Table 1. Correlation matrix for tree-ring records from the Kamchatka Peninsula. In addition to the comparisons between sites correlations of May, June and summer (May-August) temperatures for Esso and Kliuchy meteorological stations are also shown. Correlations significant at the $99 \%$ level are in bold.

\begin{tabular}{lccccccccccc}
\hline & BY & ESS & KEL & ESN & KR & KTL & BAR & SHI & SPRUCE & BIRCH & KAML \\
\hline BY & & & & & & & & & & & \\
ESS & $\mathbf{0 . 6 9}$ & & & & & & & & & & \\
KEL & $\mathbf{0 . 6 5}$ & $\mathbf{0 . 7 9}$ & & & & & & & & & \\
ESN & $\mathbf{0 . 7 5}$ & $\mathbf{0 . 6 7}$ & $\mathbf{0 . 7 9}$ & & & & & & & & \\
KR & 0.14 & $\mathbf{0 . 2 4}$ & $\mathbf{0 . 3 4}$ & $\mathbf{0 . 2 2}$ & & & & & & & \\
KTL & $\mathbf{0 . 4 0}$ & $\mathbf{0 . 4 3}$ & $\mathbf{0 . 6 3}$ & $\mathbf{0 . 5 7}$ & $\mathbf{0 . 5 4}$ & & & & & & \\
BAR & $\mathbf{0 . 5 7}$ & $\mathbf{0 . 4 2}$ & $\mathbf{0 . 5 5}$ & $\mathbf{0 . 5 9}$ & $\mathbf{0 . 3 6}$ & $\mathbf{0 . 4 0}$ & & & & & \\
SHI & $\mathbf{0 . 5 3}$ & $\mathbf{0 . 5 3}$ & $\mathbf{0 . 5 3}$ & $\mathbf{0 . 5 8}$ & $\mathbf{0 . 2 5}$ & $\mathbf{0 . 5 0}$ & $\mathbf{0 . 4 8}$ & & & & \\
SPRUCE (SHE) & $\mathbf{0 . 2 8}$ & $\mathbf{0 . 4 5}$ & $\mathbf{0 . 3 8}$ & $\mathbf{0 . 3 7}$ & $\mathbf{0 . 2 0}$ & $\mathbf{0 . 2 0}$ & $\mathbf{0 . 2 8}$ & 0.18 & & & \\
BIRCH (Av) & -0.06 & 0.17 & 0.18 & 0.10 & -0.07 & 0.02 & 0.05 & $\mathbf{0 . 2 5}$ & $\mathbf{0 . 3 2}$ & & \\
KAML & $\mathbf{0 . 7 8}$ & $\mathbf{0 . 7 5}$ & $\mathbf{0 . 8 7}$ & $\mathbf{0 . 8 7}$ & $\mathbf{0 . 3 8}$ & $\mathbf{0 . 7 5}$ & $\mathbf{0 . 7 6}$ & $\mathbf{0 . 7 4}$ & $\mathbf{0 . 3 6}$ & 0.12 & \\
Esso, T JJA & 0.33 & 0.41 & $\mathbf{0 . 6 3}$ & 0.38 & 0.22 & 0.41 & 0.27 & 0.38 & 0.03 & -0.10 & $\mathbf{0 . 4 4}$ \\
Klichi, T May & 0.21 & 0.13 & 0.20 & 0.13 & 0.22 & 0.18 & 0.20 & 0.17 & -0.06 & -0.02 & 0.17 \\
Kliuchy, T June & $\mathbf{0 . 3 6}$ & $\mathbf{0 . 4 6}$ & $\mathbf{0 . 4 3}$ & 0.20 & $\mathbf{0 . 4 1}$ & $\mathbf{0 . 4 0}$ & 0.23 & $\mathbf{0 . 3 1}$ & 0.12 & -0.01 & $\mathbf{0 . 3 9}$ \\
Kliuchy, T JJA & 0.26 & $\mathbf{0 . 3 1}$ & $\mathbf{0 . 4 3}$ & 0.28 & 0.22 & $\mathbf{0 . 3 8}$ & 0.22 & 0.26 & 0.18 & 0.11 & $\mathbf{0 . 3 7}$ \\
\hline
\end{tabular}

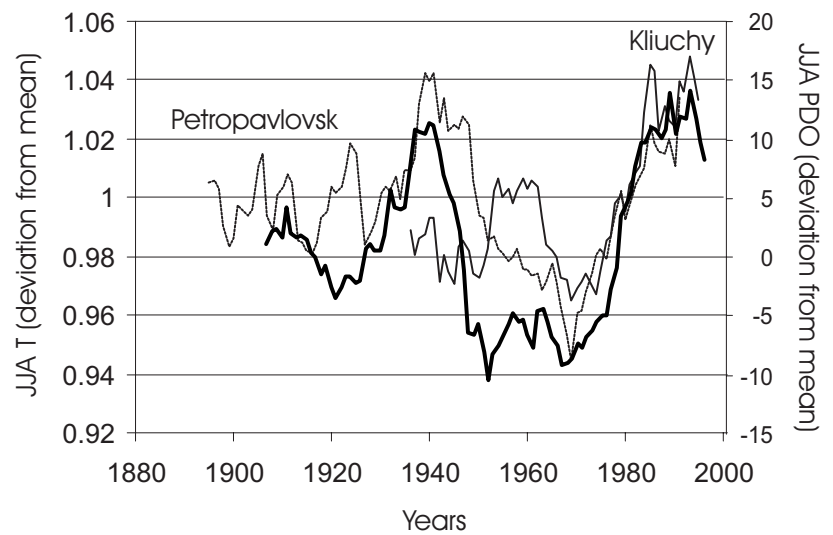

Fig. 3. JJA PDO (Mantua et al., 1997), JJA mean temperature measured at Petropavlovsk and Kliuchy meteorological stations (deviations from mean).

(SHI) and one from Kronotsky Peninsula (BAR) (Table 1, Fig. 1). In addition, a preliminary spruce (SHE) and birch (AV) ring-width series are also available from the Shiveluch and Avacha volcanoes, respectively.

Larch chronologies from Kamchatka correlate well (Table 1) with each other, except for the KR site from the active Tolbachik volcano, which may be influenced by local volcanism. One might have expected differences in climate signals between the inland larch sites and the more maritime BAR site on the Kronotsky Peninsula. However differences appear to be minor as BAR correlates well with the other larch chronologies (Table 1). The spruce chronology also compares well with the larch series, but with a weaker correlation (Table 1).
COFECHA was used (Holmes, 1983) for crossdating and quality control, and ARSTAN (Cook, 1985) for chronology development adopting a conservative detrending of negative exponential and straight line curve fits. We combined the larch series (individual samples) into a regional chronology (KAML; Fig. 4) using standard dendroclimatological procedures (Cook and Kairiukstis, 1990). The final chronology includes 144 cores for the period AD 1632-2003 with a mean series intercorrelation of 0.65 and an average mean sensitivity of 0.32 . The chronology has 22 missing rings in the years 1778, 1857, 1864, 1865, 1867, 1877, 1926, 1927 and 1947. This regional chronology compares well with the BY chronology (Gostev et al., 1996) on both annual and decadal timescales (Fig. 4), except for early in the record, when the sample size is small, and towards the end when anthropogenic disturbances are likely at the BY site after 1940.

Most tree-ring chronologies from Kamchatka are temperature sensitive and have significant correlations with May, June, and summer (JJA) temperatures (Table 1). These larch chronologies (Table 1) are better correlated with the interior Kliuchy and Esso stations than the coastal station at Petropavlovsk. The correlation of larch chronologies with summer temperature is significant and consistent, but for most of them it is not strong enough for a formal reconstruction. Therefore we use a regional larch chronology (KAML) as a better replicated and more representative of regional climate to infer summer temperature variations (see also Fig. 4).

\subsection{Ice core records}

In addition to tree-ring records from Kamchatka, ice cores reveal considerable information about past temperature and 


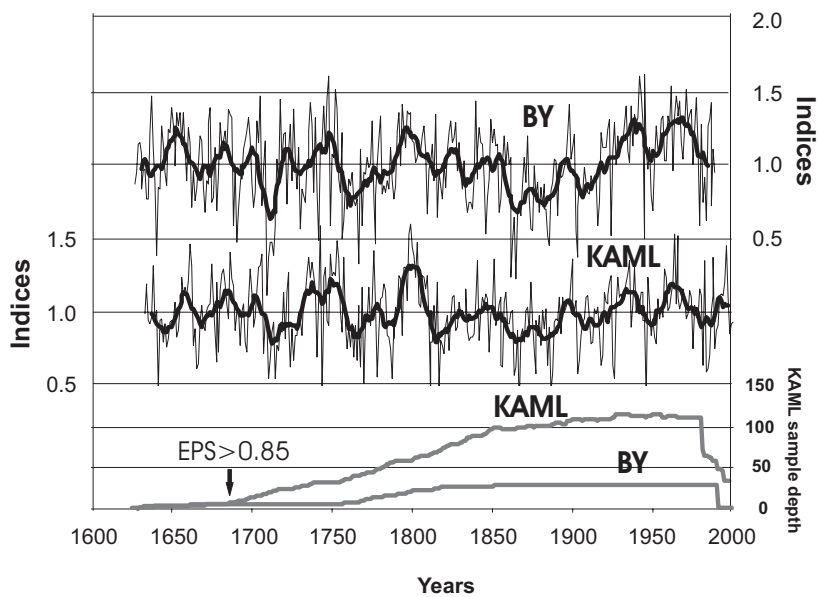

Fig. 4. Comparison of the KAML and BY ring-width standard chronologies. These records are considered to be proxies of (early) summer temperature.

precipitation variability (Shiraiwa et al., 1999). These data include a Melt Feature Index (MFI; Fig. 5a, b) linked with temperature variability, and snow accumulation data from the Ushkovsky volcano ice core in Gorshkov Crater (Shraiwa et al., 1999). This Ushkovsky ice core was recovered in 1998 to $212 \mathrm{~m}$ depth, which is approximately $28 \mathrm{~m}$ above bedrock. The average annual accumulation rate in the central part of the Gorshkov crater is estimated to be at $0.54 \mathrm{~m} \mathrm{a}^{-1}$ in water equivalent and is dated on the basis of an ash layer erupted from the Bezymianny volcano in 1956. The annual average temperature at $10 \mathrm{~m}$ depth in the core is $-15.8^{\circ} \mathrm{C}$ (Shiraiwa et al., 1999). According to annual layer counts of the Ushkovsky ice core an accuracy of the upper part of the core of $+/-2$ years is estimated to AD 1829 (Shiraiwa et al., 1999). The basal age is estimated to be between AD 1395 and 1487 according to age-depth models (Shiraiwa et al, 1999). Annual accumulation records are reconstructed from AD 1828 (Fig. 8), and the MFI extend back to AD 1503 (Fig. 5a, b).

The MFI is derived from ice inclusions of refrozen water within annual layers. In general their volume is considered as an estimate of summer temperature, although the quantification of this proxy is complicated (Koerner, 1977). Jacoby et al. (1983) previously demonstrated a correspondence between the smoothed values of MFI from Devon Ice Cap (Koerner, 1977) with reconstructed degree days above $10^{\circ} \mathrm{C}$ for June-July from a ring-width chronology from the Yukon Territory. Similarly, Solomina et al. (2000) compared a local tree ring chronology from Kamchatka with the MFI from the Ushkovsky ice core. Here we note a general agreement between the smoothed values of the MFI and KAML chronology, although the correlation is low both between the annual and smoothed values (Fig. 5a). The discrepancies may be due to the dating of the MFI series or to the different seasonality of the records.
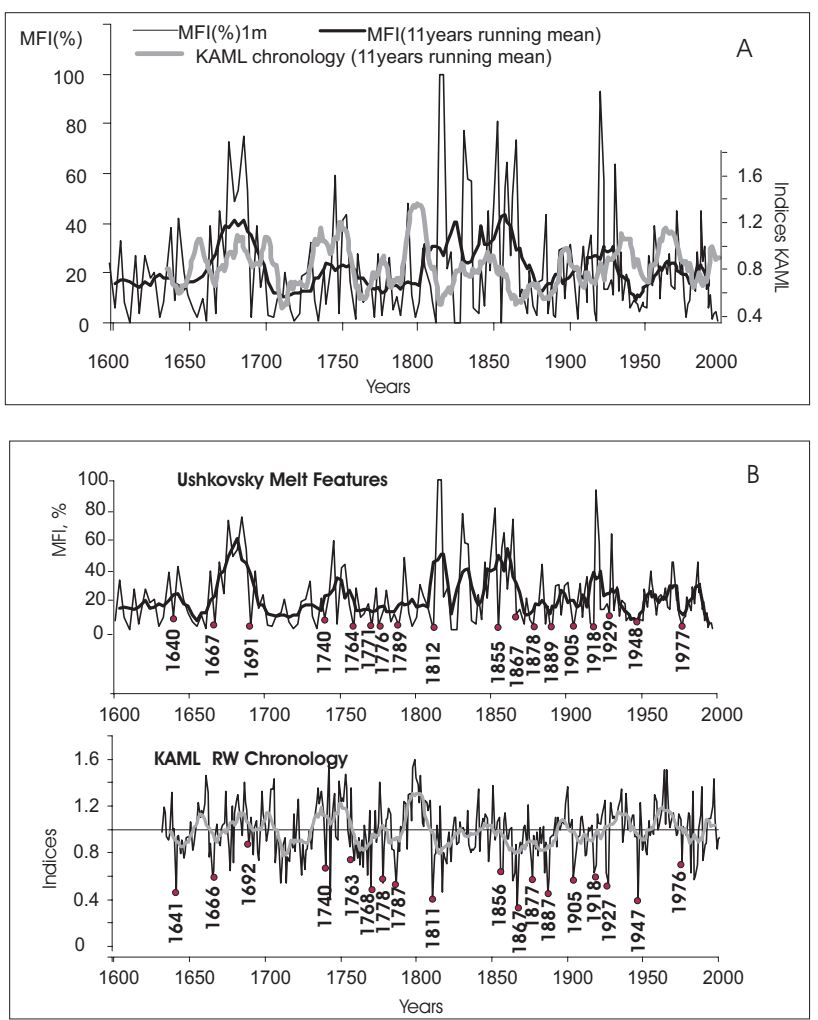

Fig. 5. (A) Smoothed values (11 year running mean) of the Melt Feature Index (MFI) of the glacier of Ushkovsky Volcano and the KAML ring-width chronology. (B) Unsmoothed values of the same parameters and dates of corresponding minima.

The strong agreement of individual minima evident in the comparison between the unsmoothed MFI and KAML chronology suggest an accuracy of the ice core dating of +/1-3 years back to AD 1750 (Fig. 5b). The earlier portions of the record do not show such agreement, most probably due to the low dating accuracy of the ice core. The maxima in both records (warm years), which are more prominent in the MFI curve, are not coherent with the ring-width chronology (Fig. 4). We suggest that this discrepancy may be due to the lower sensitivity of tree growth to unusual warmth, the more sensitive nature of the MFI to short melt intervals, and the potential of heating during the volcanic eruptions reflected in the ice cores, which may be unrelated to climatic warming (Shiraiwa et al., 2001). The 11-year running mean of Ushkovsky net accumulation rates correlate with the local Kluchy station winter $(r=0.75)$ and hydrological year precipitation ( $r=0.69)$ (both significant at $99 \%$ level). This strong relationship occurs even though the station is located about $4000 \mathrm{~m}$ lower than the ice core site. The accumulation has a clear multidecadal variability pattern and correlates with the Pacific Decadal Oscillation (PDO; Shiraiwa et al., 2001). As in the temperature records, the positive accumulation trend begins before the start of the meteorological records in the 1870s. 


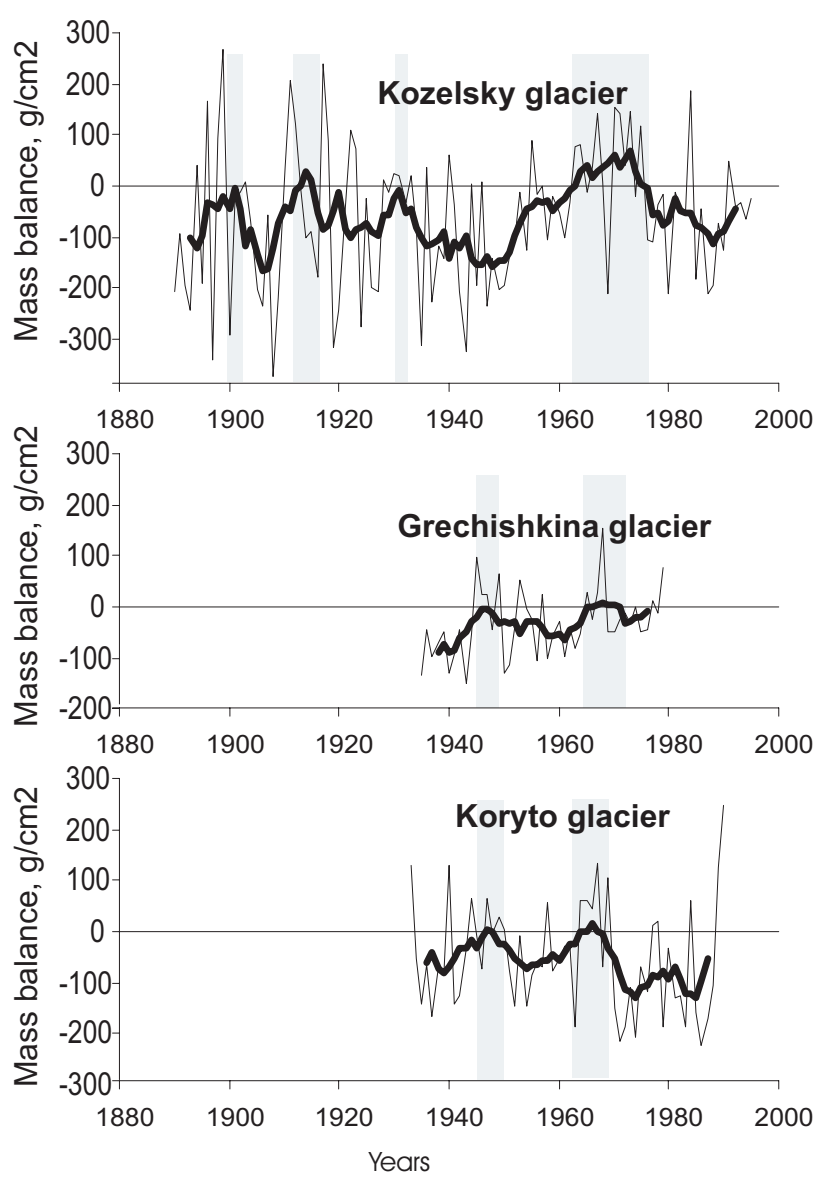

Fig. 6. Mass balance of Kamchatka glaciers reconstructed using meteorological records: Kozelsky glacier (Vinogradov, Muraviev, 1992), Grechisknia glacier (Vinogradov and Muraviev, 1985), Koryto glacier (Muraviev et al., 1999).

\subsection{Glacier variations}

The glacier record includes mass balance data both measured, and reconstructed using meteorological data (Vinogradov, 1975; Vinogradov and Muraviev, 1985, 1992; Muraviev et al., 1999) and moraine chronologies based on historical, lichenometric, tephrochronological, tree-ring, and ${ }^{14} \mathrm{C}$ dates (Solomina et al., 1995; Solomina and Calkin, 2003; Golub, 2002).

The mass balance reconstructions based on the meteorological records (Fig. 6) show that maximum positive mass balances occurred in 1960s-1970s in all three regions of Kamchatka. In response to this positive mass balance anomaly several glaciers in various regions of Kamchatka advanced. There is direct evidence of advance in the 1970s in the Kozelsky and Zavaritskogo glaciers in Avacha volcano area, at the Dvoinoy Glacier in Kliuchevskoy volcano area and for Grechishkina in the Sredinny Range. At Kapel'ka (near the Kliuchevskoy volcano, Fig. 1) and Koryto Glaciers (Kronotsky Peninsula) advanced in the 1950s-1960s. End

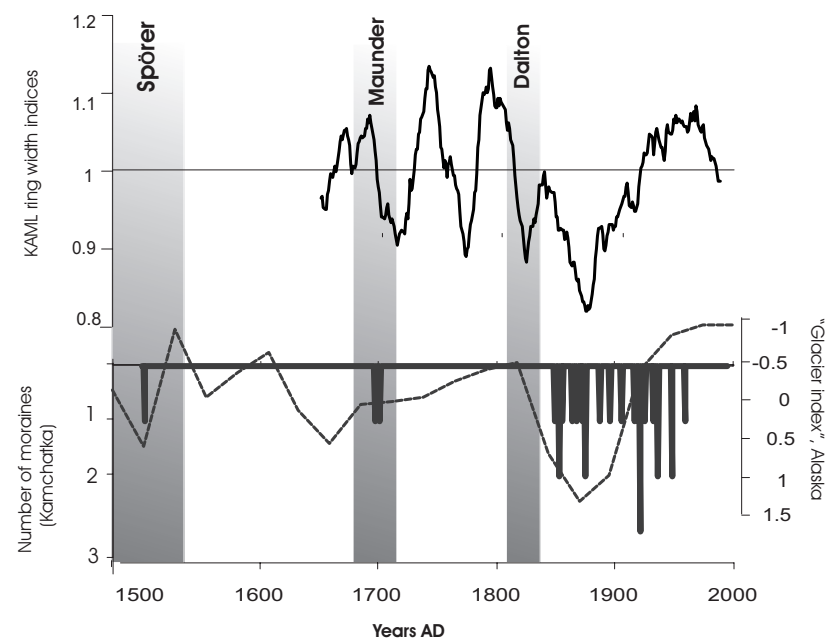

Fig. 7. Number of moraines dated by lichenometry (averaged for 20 years) in comparison with the number of advancing glaciers (normalized) in Alaska (Wiles et al., 2004), KAML ring width chronology (31-years smoothed), and solar minima.

moraines formed as result of the 1950s-1960s and 1970s advances were identified at Kozel'sky and Koryto Glaciers and were used as control points for a lichenometric growth curve (Solomina and Calkin, 2003).

In the 1940s, the balance in the south of Kamchatka was strongly negative whereas in the center and north of the peninsula it was close to zero (Vinogradov and Muraviev, 1992) (Fig. 6). In 1910s the mass balance of Kozel'sky glacier was slightly positive according to the reconstruction (Fig. 6). Eight moraines in Kamchatka are dated to the early 20th century at Novograblenogo, Elysovsky, Lavinshikov, Kozel'sky (Avacha), Koryto (Kronotsky), and Kropotkina (B.Semyachik volcano) Glaciers (Solomina et al., 1995; Solomina and Calkin, 2003) (Fig. 7) and may have been forced by these decades favorable to positive mass balance. Twelve moraines dated in Kamchatka by lichenometry, $14 \mathrm{C}$, tephrochronology, historical data and tree-ring counts (Solomina and Calkin, 2003) suggest ice advances and standstills during the 19th century. In most cases these moraines are most prominent and sometimes the only moraines preserved (Fig. 7).

Moraines older than the 19th century are rare. Two moraines deposited in 1690s-1700s are dated by lichenometry at the Avgusty Glacier on the Kronotsky Peninsula and Kozelsky Glacier in Avacha area. This dating is also supported by a tephrochronology: the moraine of Kozelsky Glacier includes the Avacha ash dated at AD 1737, but does not include an earlier reference horizon ${ }^{14} \mathrm{C}$ dated to $320+/-40$ yr. BP (GIN-6893) (1430-1650 cal yr. AD; Solomina et al., 1995). Possible earlier advance is reported by Golub (2002) based on a moraine at Kropotkina Glacier (Bolshoy Semyachik volcano) with a lichen Rhizocarpon ge- 
ographicum of $80 \mathrm{~mm}$ diameter growing on its surface. This lichen size corresponds to an age of ca. AD 1500, and is preliminary due to the poor control of the growth curve during this interval.

\section{Climate signal inferred from tree-ring and ice core proxies and glacier variations}

A combination of the Ushkovsky accumulation record (measured annual layer thicknesses) and the KAML tree-ring series as a record of summer temperature provides a basis with which to assess the potential forcing in the glacial geological records. In the regions where the moraines were dated (Avacha, Bolshoy Semyachik volcanoes, Kronotsy peninsula) the glaciers are very small (mostly less than $1 \mathrm{~km}^{2}$ ) and temperate, so they react to climate change almost immediately. For instance, many glaciers advanced or stabilized their retreat in 1970s-1980s in response to the cooling of this period. The error of the moraine dating using lichenometry, tree colonization and tephrochronology is comparable with the reaction time of the glacier tongue. Therefore, within this accuracy, and using the smoothed time series for temperature and precipitation climatic proxies we see that these comparisons are consistent with a short $(<10$ year) time lag between the climatic forcing and the glacier response reconstructed from the moraine series.

Summer temperature and winter precipitation for Kamchatka have tended to be opposite in sign in the 20th century (Fig. 8a) and therefore they either contribute together to a positive or negative glacier mass balance. Comparison of the KAML chronology with increased accumulation from Ushkovsky (Fig. 8b) shows inferred cooler intervals broadly corresponding with increased precipitation that began in the 1870s. After the removal of the linear trend between AD 1876-1989 the 20 years running means of KAML and Ushkovsky accumulation series correlate at $R=-0.49$, (99\% significance level). In the earlier portion of the record (1838-1875) the Ushkovsky accumulation rates and KAML ring width index (both 20 years smoothed) correlate positively $R=0.78$ ( $95 \%$ significance level) but neither have significant trends. In 20th century three periods favorable for glaciers (Fig. 8b) broadly coincide with those inferred from meteorological records (Fig. 8a) as well as from reconstructed mass balance (see Fig. 6) and glacial advances (see text above and Fig. 7).

The 1860s-1880s were the longest coldest interval in the last 350 years (Fig. 7). According to Gostev et al. (1996) the early summer cooling was about $1.5^{\circ} \mathrm{C}$ at that time compared with the warmest during the mid 20th century. The latest part of this period (1880s) coincided with the positive anomaly in accumulation. This coincidence led to a positive mass balance, which is most likely responsible for glacier advances and moraine deposition of the end of 19th-early 20th centuries. In many cases the advances of the end of 19th

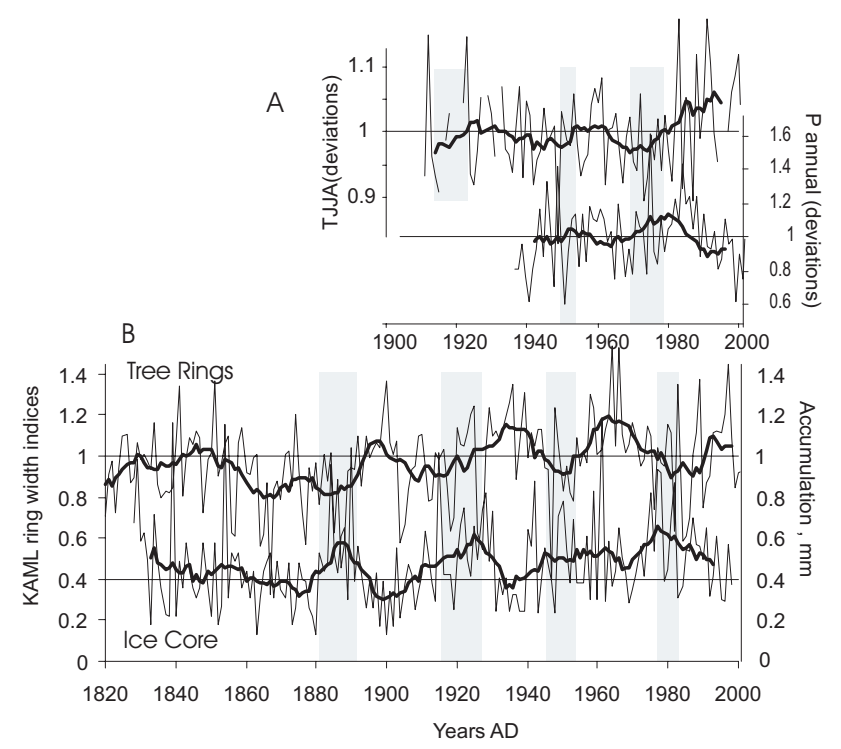

Fig. 8. (A) June-August temperature and precipitation of hydrological year (11-years smoothed) (Kliuchy met.station) (B) KAML ring width chronology (proxy for summer temperature) and accumulation for Ushkovsky ice core. All series are 11-years smoothed. Shaded stripes show periods of low summer temperature broadly corresponding to high precipitation (A - recorded, B - inferred from proxy data), i.e. favorable to glacier mass balance.

century marked the Little Ice Age (LIA) maximum, when glaciers were on the average 500-600 m longer and terminated about $100 \mathrm{~m}$ lower than at the end of 20th century (Solomina, 2000). In full agreement with subsequent summer warming trend, inferred both from instrumental and tree ring data (see Figs. 2, 7, and 8), glacier advances since 1880s have been less extensive. Climatic conditions in the 1840s1850 s were generally less favorable for glaciers due to rather high temperature and low accumulation. However the low summer temperature in 1860 s might have led to moderate glacier advances.

The available accumulation series from the ice core record ends in 1820s and therefore earlier comparisons are based on the KAML temperature record alone (Fig. 7).

Moraines have not been found equivalent to the two inferred summer temperature minima during the mid 19th and early 18th century (Fig. 7) although these moraines may have been destroyed by the later advances of the late 19th century. The late 18th century expansion coincides with the inferred summer temperature decrease recorded by the ring width chronology, however, the AD 1500 advance is too old to be compared with the ring width records.

\section{Discussion}

The AD 1500, late 18th century and late 19th century expansions are broadly consistent with the Alaskan moraine record 
(Wiles et al., 2004) (Fig. 7). A similar LIA glacial history is reported by Koch et al. (2004) for the Garibaldi Provincial Park, Southern Coast Mountains, British Columbia. The most extensive advance of the Little Ice Age occurred there in the early 18th century, but the moraines of late 19th century are close to this Little Ice Age maximum. The glacier retreat began about 150 years ago, but occurred mostly during two intervals, between 1930 and 1960 and between the late 1970s and present. The two retreat phases were separated by a stillstand or minor re-advance in the late 1960s and early 1970s. Luckman (2000) reported the history of glacier fluctuations during Little Ice Age in the Canadian Rockies and identified the episodes of glacier advances during the "high" LIA that occurred in the early 18th, through the 19th centuries, with glacier retreat in the 20th century. Both periods of glacier advances follow periods of reduced summer temperatures in 1690s and in the 1800s. According to the tree-ring reconstruction in the Canadian Rockies the precipitation were higher than average in the 1880 s, precisely at the same time as in Kamchatka according to the ice core records. Glacier advances in the early 1700 s, the late 1800 s and, in the 1950-1970s, reflect both increased precipitation, and reduced summer temperatures. The similarity of this pattern with Kamchatka records for the last two advances is also striking. However while in the Rockies Mountains the negative glacier mass balances from 1976 to 1995 were caused by decreased winter precipitation, in Kamchatka it was due both to increased summer temperature and decreased winter precipitation.

At the first glance the reconstruction of mass balance index for the Jackson and Agassiz glaciers in the Glacier National Park, Montana, USA, by Pederson et al. (2004) based on PDO (winter balance) and tree-ring width density (summer balance) do not show a similarity to Kamchatka records. According to this reconstruction the maximum LIA advances coincided with cool summers and high winter precipitation in 1770s-1790s and in 1800s-1830s. In 1860s-1890s the mass balance in Glacier National Park was negative due to both high ablation and low accumulation and the glaciers start to retreat. In Kamchatka the major cooling and glacial advance occurred exactly at the time of this retreat. However the periods of coolings in the late 18th and early 19th centuries are recorded in Kamchatka as well as in Glacier National Park, though their amplitude is different and smaller than in the end of 19th century. The absence of moraines coinciding with these coolings is explained by the most extensive glacier advance in the late 19th century (see above).

The similarity of the last half-millennium glacial history in Kamchatka and Alaska/Rockies Mountains may partly explain the absence of moraines that predate the 15th century in Kamchatka. A millennium-long tree ring summer temperature record in Alaska (Wilson et al., 2007) shows the generally warmer summers in the area in 11th-14th centuries, when the glaciers were smaller than in the 15th-19th centuries.
The strong advances in the late 1800s, late 1600s and possible expansion ca. AD 1500 correspond with and may have been partially forced by a decrease in solar radiation during the Dalton, Maunder and Sporer solar minima as reported in Alaska (Wiles et al., 2004) (see Fig. 7) and in the Canadian Rockies (Luckman and Wilson, 2005). The broadly coherent glacier variations at these times across the North Pacific suggest similar forcing from both regions, which is generally consistent with solar forcing, but could also reflect changes in the PDO which is also common to these areas.

Similar to Kamchatka, the late LIA maximum (in the late 19th-early 20th century) occurred in several other high latitude regions, such as Western Greenland (Ten Brink and Weidick, 1974), Iceland (Gudmundsson, 1997), Spitsbergen (Werner, 1990), the Polar Urals (Solomina, 2003), Franz Jozef Land (Lubinsky et al., 1999), in the east Brooks Range (Calkin and Wiles, 1991). This study shows that in Kamchatka this advance was triggered by a long deep summer temperature minimum in $1860 \mathrm{~s}-1880$ and a accumulation maximum in 1880 s.

Collectively the proxy records suggest that there was probably a change in character of circulation in the region in 1870s. This variation is first detected in the change from positive to negative correlation of the KAML and Ushkovsky data about 1875. After 1875 cooler summer temperatures are associated with increased winter precipitation together forcing the major late 1800 s moraine building maximum. Similar variations in proxy records have been detected for the North Pacific and the Pacific basin in general. Earlier comparisons of tree-ring records from Hokkaido Japan and Kamchatka showed that temperature-sensitive series, from the two regions were coherent from the early 15 th century through the mid 1800s after which the relationship noticeably weakened (Davi et al., 2002). Villalba et al. (2001) also identified a breakdown in the decadal mode of variability after AD 1850, based on a larger inter-hemispheric comparison of Gulf of Alaska and Patagonia tree-ring records, and suggested that it may be attributed to a more energetic ENSO tropical forcing.

Glaciers in Kamchatka are decreasing in size as most mountain glaciers in the World (Grove, 2004). The advance of 1970s was by far less prominent than the LIA advances and those of the beginning of 20th century, while documented increases in precipitation have not counterbalanced the mass loss due to the ablation. Its timing approximately coincides with the PDO shift in the North Pacific in the maritime southern Kamchatka, whereas in more northern regions and in central Kamchatka the positive shift took place earlier, in the 1960's.

Not only the decadal variations, but also individual summer temperature minima in Kamchatka inferred from the KAML ring width chronology are common for the North Pacific region and more broadly for the Nothern Hemisphere. Thus, several known volcanic eruptions recognized in the KAML tree-rings (e.g. in 1641, 1695, 1810, 1816, 1831) are marked as by narrow rings both in the Wrangell Mountains of 
southern Alaska (Davi et al., 2002) and the Northern Hemisphere records (D’Arrigo et al., 2001).

\section{Conclusions}

Tree rings, ice cores and glacial geologic histories characterize climate variability and identify the key climate parameters forcing glacier expansions for Kamchatka over the past several centuries.

The KAML larch ring-width chronology provides a proxy record of past summer temperature variability for the period AD 1632-2003 in Kamchatka. Comparison of the KAML chronology ring width minima with the Melt Feature Index in Ushkovsky ice core record suggests a 1-3 year dating accuracy for the ice core from the late 18th to 20th centuries. Individual low growth years in the larch record are associated with several known and inferred volcanic events recognized from other proxy records from the Northern Hemisphere.

Since the 1870 s -1880 s the decadal variations of annual accumulation and larch ring width in Kamchatka tend to be opposite. This pattern is consistent with the observed fluctuations of annual precipitation and summer temperature in 20th century. The periods of high accumulation and low summer temperature favorable for the glaciers are identified by these records as 1880s, 1910s-1920s, 1940s-1950s and 1970s. The positive linear trend for both summer temperature and annual precipitation began in 1870 s-1880s. In accordance with this trend glaciers retreated from the LIA maximum during the 20th century. The minor advances of glaciers in 1940s-1950s and 1970s are instrumentally recorded and supported by mass balance reconstructions from instrumental data, while those for the beginning of the century are supported by the dated moraines in both maritime and continental parts of Kamchatka.

The glacier record shows moraine building about AD 1500 , during the final decade of the 17 th century, a strong expansion during the late 1800 s and mostly negative mass balance with short positive excursions during the 20th century. Comparisons of this glacier history with records from Alaska and the Canadian Rockies suggests broadly consistent intervals of glacier expansion and inferred summer cooling during solar irradiance minima.

Acknowledgements. The study was supported by National Science Foundation Grant ATM02-02898, and International Science and Technology Center, Grant 2947. We would like to thanks Brian Luckman for valuable comments.

Edited by: J. Brigham-Grette

\section{References}

Calkin, P. E. and Wiles, G. C.: Little Ice Age glaciation in Alaska: a record of recent global climatic change, Int. Conf. on the role of the Polar regions in global change, Fairbanks, p. 617-625, 1991.
Chinn, T. J.: New Zealand glacier response to climate change of the past two decades, Global and Planetary Change, 22, 155-168, 1999.

Cook, E. R. and Kairiukstis, L. A.: Methods of dendrochronology: applications in the environmental sciences, Dordrecht, Netherlands, Kluwer Academic Publishers, 1990.

Cook, E. R.: A Time Series Analysis Approach to Tree-Ring Standardization, Ph.D. Thesis, University of Arizona, Tucson. 1985.

D’Arrigo, R. J., Jacoby, G., Frank, D., Pederson, N., Cook, E., Buckley, B., Nachin, B., Mijiddorj, R., and Dugarjav, C.: 1738 Years of Mongolian Temperature Variability Inferred from a Tree-ring Width Chronology of Siberian Pine, Geophys. Res. Lett., 28(3), 543-546, 2001.

D’Arrigo, R. D., Mashig, D., Frank, D., Jacoby, G., and Wilson, R.: Reconstructed warm season temperatures for Nome, Seward Peninsula, Alaska since AD 1389, Geophys. Res. Lett., 31, L09202, doi:10.1029/2004GL019756, 2004.

Davi, N. K., Jacoby, G. C., and Wiles, G. C.: Boreal temperature variability inferred from maximum latewood density and treering width data, Wrangell Mountain region, Alaska, Quatern. Res., 60, 252-262, 2003.

Davi, N., D'Arrigo, R. D., Jacoby, G., Buckley, B., and Kobayashi, O.: Warm-season to decadal temperature variability for Hokkaido, Japan, inferred from maximum latewood density (AD 1557-1990) and ring width data (AD 1532-1990), Clim. Change, 52, 201-217, 2002.

Golub, N. V.: Moraine complex of Kropotkina glacier as a record of glacier fluctuations in 17th-20th centuries, Data of Glaciological Studies, 93, 178-181, 2002 (in Russian).

Gostev, M., Wiles, G., D’Arrigo, R., Jacoby, G., and Khomentovsky, P.: Early summer temperature since 1670 A.D. for Central Kamchatka reconstructed based on a Siberian larch tree-ring width chronology, Can. J. For. Res., 26, 2048-2052, 1996.

Grove, J. M.: Little ice ages: ancient and modern, New York, Routledge, 2004.

Gudmundsson, H.: A review of the Holocene environmental history of Iceland, Quatern. Sci. Rev., 16, 81-92, 1997.

Hoelzle, M., Haeberli, W., Dischl, M., and Peshke, W.: Secular glacier mass balances derived from cumulative glacier length changes, Global Planet. Changes, 36, 295-306, 2003.

Holmes, R. L.: Computer-Assisted Quality Control in Tree-Ring Dating and Measurement, Tree-Ring Bull., 44, 69-75, 1983.

Jacoby, G. C., Cook, E. R., and Ulan, L. D.: Reconstructed Summer degree days in Central Alaska and Northwestern Canada since 1524, Quatern. Res., 23, 18-26, 1985.

Jacoby, G., Solomina, O., Frank, D., Eremenko, N., and D’Arrigo, R.: Kunashir (Kuriles) Oak 400-year reconstruction of temperature and relation to the Pacific Decadal Oscillation, Palaeogeography, Palaeoclimatology, Palaeoecology, 209, 303-311, 2004.

Koch, J., Menounos, B., Clague, J., and Osborn, G. D.: Environmental Change in Garibaldi Provincial Park, Southern Coast Mountains, British Columbia. Geosci. Can., 31(3), 127-135, 2004.

Koerner, R. M.: Devon Ice Cap: ice core stratigraphy and paleoclimate, Science, 196(4285), 15-18, 1977.

Lubinsky, D. J., Forman, S. L., and Miller, G. H.: Holocene glacier and climate fluctuations on Franz Josef Land, Arctic Russia, $80^{\circ}$ N, Quatern. Sci. Rev., 18, 87-108, 1999.

Luckman, B. H: The Little Ice Age in the Canadian Rockies. Geo- 
morphology. 32(3), 357-384, 2000.

Luckman, B. H. and Wilson, R. J. S.: Summer temperatures in the Canadian Rockies during the last millennium: a revised records, Clim. Dyn., 24, 131-144, 2005.

Mantua, N. J., Hare, S. R., Zhang, Y., Wallace, J. M., and Francis, R. C.: A Pacific Interdecadal Climate Oscillation with Impacts on Salmon Production, Bull. Amer. Meteorol. Soc., 76, 1069-1079, 1997.

Muraviev, Y. D., Shiraiwa, T., Yamaguchi, S., Matsumoto, T., Nishimura, K., Kohshima, S., and Ovsyannikov, A.: Mass balance of glacier in condition of maritime climate - Koryto glacier in Kamchatka, Russia, Cryospheric Studies in Kamchatka, 2, 5161, 1999.

Nesje, A. and Dahl, S. O.: The Little Ice Age - only temperature?, The Holocene, 13(1), 139-145, 2003.

Oerlemans, J.: Glaciers and Climate Change, Lisse, Abingdon, Exton (PA), Tokyo, 2001.

Pederson, G. T., Foger, D. B., Gray, S. T., and Graumlich, L. J.: Decadal-scale climate drives for glacier dynamics in Glacier National Park, Montana, USA, Geophys. Res. Lett., 31, L12203, doi:10.1029/2004GL 019770, 2004.

Patterson, W. S. B.: The physics of glaciers: ButterworthHememann, Oxford, 1994.

Shiraiwa, T., Muraviev, Ya. D., and Yamaguchi, S.: Stratigraphic features of firn as proxy climate signals at the summit ice cap of Ushkovsky Volcano, Kamchatka, Russia, Arc. Alp. Res., 29(4), 414-421, 1997.

Shiraiwa, T., Muravyev, Y. D., Kameda, T., Nishio, F., Toyama, Y., Takahashi, A., Ovsyannikov, A. A., Salamatin, A. N., and Yamagata, K.: Characteristics of a crater glacier at Ushkovsky volcano as revealed by the physical properties of ice cores and borehole thermometry, J. Glaciology, 47(158), 423-432, 2001.

Shiraiwa, T., Nishio, F, Kameda, T., Takahashi, A, Toyama, Y., Muraviev, Ya., and Ovsyannikov, A.: Ice core drilling at Ushkovsky ice cap, Kamchatka, Russia, Seppyo, 61(1), 25-40, 1999.

Solomina, O. N.: Mounatin glaciation of Northern Eurasia in the Holocene (Gornoye oledeneniye Severnoy Evrazii v Golotsene), Moscow, Nauchniy Mir, 1999 (in Russian).

Solomina, O.: Retreat of mountain glaciers of northern Eurasia since the Little Ice Age maximum, Ann. Glaciol., 31, 26-30, 2000

Solomina, O. N.: Fluctuations of subpolar glaciers over the last 2000 years by lichenometric data, Data of glaciological studies, 94, 17-30, 2003 (in Russian).
Solomina, O. and Calkin, P.: Lichenometry as Applied to Moraines in Alaska, USA, and Kamchatka, Russia, Arctic, Antarctic, and Alpine Research, 35(2), 129-143, 2003.

Solomina, O., Jacoby, G., D’Arrigo, R., Braeunning, À., Eremenko, N., and Muraviev, Ya.: Summer Temperature Reconstructions of the Last 400 Years in Kamchatka and Kunashir Based on TreeRing Analysis, Problems of ecological monitoring and ecosystem modeling, 20, 37-58, 2005 (in Russian).

Solomina, O. N., Muravyev, Ya. D., and Bazanova, L. I.: Little Ice Age Glaciers in Kamchatka, Ann. Glaciol., 21, 240-244, 1995.

Solomina, O. N., Muraviev, Ya. D., Braeuning, A., Shiraiwa, T., and Shiyatov, S. G.: Tree-rings in Central Kamchatka in Comparison with Climate Variations and Ice Core Data, Proceedings of the International Conference on Climate Change and Variability, Tokyo, Japan, 133-137, 2000.

Ten Brink N. W. and Weidick, A.: Greenland Ice Sheet History since the Last Glaciation, Quatern. Res., 4, 429-440, 1974.

Villalba, R. D., Cook, E. R., Jacoby, G. C., and Wiles, G.: DecadalScale Climatic Variability Along the Extratropical Western Coast of the Americas: Evidence from Tree-Ring Records, Interhemispheric climate linkages, edited by: Markgraf, V., San Diego, Academic Press, 155-174, 2001.

Vinogradov, V. N. and Muraviev, Ya. D.: Kozel'sky Glacier. (Lednik Kozel'sky), Sankt-Petersbourg, Gidrometeoizdat, 1992 (in Russian).

Vinogradov, V. N. and Muraviev, Ya. D.: Regime of glaciers in volcanic regions of Kamchatka, Glaciol. Stud., 27, 36-50, 1985 (in Russian).

Vinogradov, V. N.: Modern glaciation of the regions of active volcanism. Moscow, Nauka, 1975 (in Russian).

Werner. A.: Lichen growth rates for the Northwest coast of Sptisbergen, Svalbard, Arctic and Alpine Research, 1990, 22(2), 129140.

Wiles, G., D'Arrigo, R., and Jacoby, G.: Gulf of Alaska atmosphere-ocean variability over recent centuries inferred from coastal tree-ring records, Clim. Change, 38, 289-306, 1999.

Wiles, G., D'Arrigo, R., Villalba, R., Calkin, P., and Barclay, D. J.: Century-scale solar variability and Alaskan temperature change over the past millennium, Geophys. Res. Lett., 31, L15203, doi:10.1007/s00382-006-0194-9, 2004.

Wilson, R., Wiles, G., D'Arrigo, R., and Sweck, C.: Cycles and shifts: 1300 years of multidecadal temperature variability in the Gulf of Alaska, Clim. Dyn., 28, 424-440, doi:10007/s 00382006-0194-9, 2007. 